\title{
UN BAILE DE MÁSCARAS: LA EXPRESIÓN CARNAVALESCA DE LA REALIDAD
}

\author{
José Ángel Vargas \\ Y así uno puede reírse, y creer que no está hablando en serio, \\ pero sí se está hablando en serio, la risa ella sola ha cavado \\ más túneles útiles que todas las lágrimas de la tierra. \\ Julio Cortázar. \\ Rayuela.
}

\begin{abstract}
RESUMEN
Este artículo tiene como tema principal el estudio de la novela Un baile de máscaras (1995), del escritor nicaragüense Sergio Ramírez Mercado, principalmente en cuanto a los recursos que permiten la expresión carnavalesca de la realidad, enfatizando en la parodia, el humor y la ironía.
\end{abstract}

\begin{abstract}
The main topic in this article is the survey of the novel Un baile de máscaras (1995) by Sergio Ramírez Mercado. It is based on the resources that allow the carnival expresión of the reality, with an emphasis on the parody, humor and irony.
\end{abstract}

\section{Introducción: Hacia una escritura lúdica}

En las obras anteriores a la publicación de Un baile de máscaras (1995), Sergio Ramírez había intentado aprovechar al máximo las posibilidades expresivas del lenguaje. Sin embargo, el matiz ideológico político que se les asignaba constituía una limitación para ello. O quizá, la misma percepción de la realidad del autor, marcada por la formación de una conciencia revolucionaria, mediaba en su manera de tratar el lenguaje. La denuncia de la dictadura y del poder que realiza en obras como Tiempo de fulgor (1970), De tropeles y tropelías (1973), Charles Altas también muere (1976) y ¿Te dio miedo la sangre? (1977) alcanza importantes niveles de elaboración artística.

Es evidente que la realidad histórica y política tiene una repercusión importante en sus obras, pero el mérito del autor está en ir buscando las formas más adecuadas para lograr una escritura en la que se supera la denuncia directa y se ahonda en la crítica, confiriéndole, además, a las narraciones, un tono lúdico. Así, en Tiempo de fulgor hay un claro predominio de un ambiente de tensión y dolor, provocado por una guerra en la que prácticamente se ven envueltos todos los personajes y que se constituye en una sombra que afecta la vida cotidiana, pues no hay espacio alguno para la tranquilidad. Por el contrario, el fulgor de la guerra 
abrasa a toda la población y se palpa en los cañonazos que retumban constantemente, así como en las enfermedades y en la muerte. Pero aún en este clima, Ramírez crea espacios para el humor que, sin dejar de tener un cierto tono negativo, suavizan la narración y dan al lector la posibilidad de una pausa que lo libera momentáneamente del mundo sórdido y atormentador de la guerra. Se trata concretamente de dos casos; en el primero, se narra la actitud del médico José Trinidad:

Y José Trinidad estudió Medicina en Francia y murió loco y soltero porque no le tocó ninguna Contreras virgen a la qué desposar cuando regresó de sus quince años en París y comenzó a enloquecer, negándose a cerrar las heridas de sus pacientes tendidos en la mesa de operaciones mientras no se le entregaran los honorarios (Ramírez 1970: 158) ${ }^{1}$,

mientras que, en el segundo, el narrador se refiere a las relaciones incestuosas promovidas por Belisario Contreras:

Juan Félix Contreras regresó a Nicaragua cuando ya los miembros de la familia se contaban con los dedos de la mano, se había disipado todo su lustre y poderío y los que aún quedaban habían violado la primera regla fijada por Belisario Contreras en sus cánones, de casarse solo entre primos hermanos para mantener la pureza de la sangre y el legado real de la nobleza que con tanto esfuerzo les había sido concedido (161) ${ }^{2}$.

En De tropeles y tropelías, el haber escogido la fábula como modalidad discursiva le abre espacios para jugar con el lenguaje, sin dejar de lado la denuncia política. Ello le da mayor libertad para efectuar un tratamiento certero y burlesco del mundo de la dictadura, encarnado en un personaje que se denomina alegóricamente Su Excelencia, como se observa a continuación:

a) El día onomástico del Señor Presidente, o en el de su cumpleaños, se le presentará respetuoso y atento saludo de felicitación, así: por la mañana, después de la diana, clases y alistados de la fuerza armada; por la tarde, antes del brindis, suboficiales y oficiales de la fuerza armada; después del brindis, ministros, viceministros y demás funcionarios; por la noche, antes de los juegos pirotécnicos, pueblo en general; después de los juegos pirotécnicos, fuerzas vivas de la nación. Después del baile de gala, damas y damitas a discreción. ${ }^{3}$

b) Durante el juego que se hacía sobre una capa dispuesta en el suelo, a la luz de las lámparas de carburo colgadas de la mampostería, se pasaron copas pues S.E. gustaba del 'Anís del Mono'. Ya ebrio y perdiendo repetidas veces, alegó que el Ministro de Guerra le estaba robando con los dados cargados que disimuladamente tiraba al tapete.

El Ministro protestó su inocencia y lealtad, poniéndose de pie y cuadrándose, pero fue prendido y antes de partir S.E. para las avanzadas de la línea de fuego, ordenó su fusilamiento por alta traición.

Al despertar al día siguiente en algún lugar de la montaña, preguntó por el Ministro para preparar la estrategia y al referirle su edecán el episodio de la noche anterior, ordenó furioso que volaran en postas a impedir la ejecución.

Sin embargo, el mandamiento llegó tarde porque el Ministro había sido ejecutado al no más amanecer (p. 51).

c) S.E. fue abogado antes de asumir los más altos poderes de la nación. Se graduó en una oscura Facultad de Leyes de provincia y antes de obtener el título fue rábula, copiador de sentencias, amanuense, peleador de gallinas, secretario de juzgados penales, defensor de Iglesia en litigios por fundos y aparcerías que se llevaban y discutían en estrados usando la lengua latina.

Ya con el título en la mano hundió en calamidades a gentes rústicas, arruinó a familias enteras, se apropió de heredades, deshaució a cientos de colonos y precaristas, borró caminos medianeros, usurpó derechos de viudas, su fortuna la amasó a base de despojos e hipotecas y la cuantía de sus bienes podía medirse por la cantidad de pleitos judiciales que logró ganar con prevaricatos y sobornos (39).

d) Al fallecer S.E. un día aciago, erigirle una estatua fue simple tarea de disecarlo, con todo y caballo (36). 
En general, los textos que componen este libro construyen una imagen nefasta y degradada del poder, apoyándose en el humor y la ironía con que es tratado el personaje S.E (o Señor Presidente) del que el autor efectúa una constante burla, mostrando sus aberraciones y contradicciones, de manera que la fábula funciona entonces como una estrategia narrativa para desentrañar los problemas del poder político, sin citar directamente hechos y personajes reales ${ }^{4}$.

También en Charles Atlas también muere se continúa ese intento de una escritura lúdica y catártica, que se produce por el sarcasmo y las notas humorísticas que aparecen en las narraciones, principalmente en el cuento "El centerfielder", en el que se aprecian rasgos de una literatura lúdica, los cuales provienen de la concepción del cuento como un juego, aspecto destacado por Jorge Febles (1996: 58), para quien el autor aprovecha el tema del juego y el carnaval para revelar cómo ha sido la represión de las clases bajas durante la dictadura somocista ${ }^{5}$.

En ¿Te dio miedo la sangre?, pese al ambiente sombrío y nefasto, generado por la dictadura, hay escenas que apuntan hacia un ludismo, como ocurre con los personajes que visitan con frecuencia el burdel de Lasinventura, espacio donde se encuentran para compartir ampliamente sus experiencias. Lasinventura ${ }^{6}$, dueña del lugar, es una mujer muy espontánea y alegre, que escucha a los demás y bromea con ellos, a cuyo mando están Las Adelantadas (La Colegiala, Fátima Fatal y La Niña de las Rosas); recibe a todo tipo de personas, incluso al General Ubico le concedió el honor de "catar" a las jóvenes que ingresaban al burdel; les permite al Turco, Jenaro, Catalino y Taleno que tomen licor excesivamente, declamen y canten. De esta manera, el burdel se convierte en un lugar carnavalesco porque ahí los personajes encuentran placer, sexo, alegría, música, y también pueden discutir diversos temas:

\footnotetext{
El Jilguero inició el refuego con la guitarra y se abrió la cantadera, logrando el Indio tras mucha insistencia, sacarle voz al Coronel, que enredaba las letras pero secundaba en el coro; venían fritangas de la cocina y más hielo quebrado y más limones, venían aguas gaseosas, movilizándose admirablemente Las Adelantadas mientras estuvieran sobrias. Al suelo iban cayendo, hechas ya cadáveres, las botellas.

En una de tantas, el Indio se subió de un solo brinco a la mesa y comenzó a bailar un son con el pañuelo en alto, desatando en su zapato una quebradera de vasos y de platos; la maroma del Indio divirtió al Coronel, quien empezó a llevarle el compás, golpeando con las palmas de las manos sobre las piernas de La Colegiala; y en eso estaban cuando vos, Jilguero, por joder o lo que fuera le cambiaste de pronto el ritmo, te pasaste a un bolero sentimental, y arriba el Indio paró sus vueltas; buscando equilibrio bajó primero a una silla y de allí al suelo, y sin osar mirarnos para que no nos riéramos en su cara, amoscado, se enjugaba la frente.

Después de apear al Indio de la mesa, el Jilguero ya se quedó tocando solo piezas de llanto, nadie podía seguirle con la voz sus canciones viejas, unos aires serenateros que la Fátima Fatal y la Niña de las Rosas bailaban descalzas, estrechándose sonámbulas a los cuerpos de unos compañeros invisibles (Ramírez 1977: 108-9) ${ }^{7}$.
}

Estos esfuerzos escriturales encaminados hacia una escritura lúdica abren un espacio muy significativo en la obra del autor y anuncian un nuevo modo de abordar la realidad; no obstante, se quedan en un intento de carnavalización de la escritura, porque en realidad ninguna de las obras señaladas logra destruir plenamente la jerarquía del poder, debido a que el juego y la fiesta se silencian y se imponen la represión, el miedo y la muerte. 


\section{Un nuevo giro en la narrativa de Sergio Ramírez}

Al igual que Castigo Divino (1988), Un baile de máscaras (1995) es parte de esa decisión del autor de alejarse del tema de la Revolución Sandinista. Esta vez ha ubicado la acción en la década de los cuarenta y en forma muy específica en el año 1942. Se aprecia así su inclinación por retomar una secuencia temporal en sus narraciones y de ese modo ir abarcando fragmentos concretos de la historia nicaragüense y centroamericana, pues Castigo Divino comprende el contexto de la década de 1930 y Un baile de máscaras mantiene ese interés por tratar la realidad social, pero el autor ha procurado un giro muy significativo, al menos en cuanto a la temática: novela sus raíces y eso lo lleva a incursionar en el ámbito de su familia y centrar la narración en los acontecimientos previos a su nacimiento, el día 5 de agosto de 1942, con lo cual la obra adquiere una connotación biográfica.

El primer epígrafe de la obra, tomado de T.S. Elliot: "And the end of all our exploring/ Will be to arrive where we started/ And know the place for the first time" 8 recoge su intención de interpretar aquellos momentos y aspectos que han resultado claves en su vida: su familia y la Nicaragua de los años cuarenta. Consciente de que el final de todos sus esfuerzos revolucionarios, políticos y culturales, será explorar su existencia, emprende esta nueva aventura literaria en la que la focalización está puesta en la vida familiar, pero paralelamente hay una preocupación por examinar el todo social, como parte de la vertiente crítica que caracteriza su obra.

Arnoldo Mora Rodríguez observa la diferencia que, a su criterio, existe entre Castigo Divino y Un baile de máscaras. Para él, estriba en el carácter intimista de la narración y también en el tipo de lenguaje empleado:

\footnotetext{
Un baile de máscaras, por el contrario, pertenece al género más intimista. Mantiene de común con la obra anterior la preocupación central del autor por describir una época y el mundo cultural de su propio pueblo, pero lo hace no a través de la crónica histórica de un hecho célebre, cuyos aspectos escandalosos conmovieron al país y dividieron a una ciudad entera en bandos irreconciliables hasta hoy, sino gracias a la anécdota cotidiana, narrada con la gracia picaresca y desenfadada del lenguaje coloquial, con el que se viven y narran situaciones de la vida diaria en el seno de una familia -que es la propia del autor-perteneciente a la clase media de una pequeña ciudad de provincia ${ }^{9}$.
}

Esta diferencia apuntada por Arnoldo Mora se reafirma también desde el punto de vista de la técnica narrativa. El narrador omnisciente que predominaba en Castigo Divino ha cedido el espacio al monólogo interior y a la narración desde la conciencia individual, con lo que los hechos son mirados desde la óptica de los personajes que se sienten integrados en ese entorno. Toda referencia al exterior parte de ese microcosmos y está mediatizada por las peculiaridades sociales, ideológicas y culturales de la familia.

El autor expresa que disfrutó mucho escribiendo la novela, tanto por la temática como por la forma de narrar, la cual sirve para presentar los hechos de un modo fluido y espontáneo, y sobre todo, para mostrar la visión particular que cada personaje tiene de su entorno y de los demás personajes. Por otra parte, cuando Víctor Hugo Fernández (1995: 1) lo interroga sobre el carácter autobiográfico de la novela, Ramírez responde:

Sí; lo es en buena parte. La tía embarazada de la novela es mi propia tía y el hombre que sale a buscar a quien la dejó embarazada para que se case con ella es mi padre. La familia que da unidad a la obra es mi familia, pero también hay material novelado en torno a ello; hay ficción y muchas cosas que surgen de la imaginación ${ }^{10}$. 
Este matiz autobiográfico de la obra funciona como un recurso verosimilizante, pues remite al lector a una época y a una realidad concreta, de manera que el sentido de la obra se va construyendo con base en el diálogo entre lo autobiográfico y lo ficcional, entre los hechos reales y la imaginación, un diálogo que el escritor explota gracias a la selección y concurrencia de diversos elementos sociales y culturales.

Según el autor, ha mantenido el nombre de los abuelos y de sus padres, pero ha inventado o modificado el de los tíos porque en estos últimos hay un mayor trabajo de imaginación: "Los personajes son verídicos, mis padres y mis abuelos conservan hasta su propio nombre; con los tíos y los demás personajes invento los nombres porque tienen contenidos más imaginativos" (En Dobles 1995: 1) ${ }^{11}$. De este modo, el autor juega con la referencialidad textual; a partir de personajes reales y concretos despliega un mundo imaginativo para crear otros personajes a su manera, enfatizando aquellos rasgos que considere pertinentes, según sus propósitos.

\section{La historia como telón de fondo}

Un baile de máscaras narra detalladamente los hechos previos al nacimiento del hijo de Pedro y Luisa, el día 5 de agosto de 1942, y al baile de disfraces que por la noche de ese mismo día ha organizado Saulo Regidor y su esposa Adelina Mantilla. Los personajes pasan las horas preocupados por prepararse para asistir a esta actividad, la cual será amenizada por la Orquesta Ramírez, dirigida por el abuelo Lisandro. Pero en el transcurso del día ocurren varios acontecimientos que alteran el orden cotidiano, como la muerte de Diocleciana Putoya, madre de las hechiceras; el suicidio de Macabeo Regidor, hermano de Saulo; y diversas riñas o peleas entre los miembros de la familia y otros ciudadanos del pueblo, a lo cual se le suma una torrencial lluvia que parece un diluvio. Finalmente, el baile no se realiza como estaba previsto y la obra culmina con la alegría de los padres por el niño que ha nacido.

La importancia que se le concede al mundo familiar es capital: hay un esmero por presentar las características y relaciones entre las familias Mercado y Ramírez, de las cuales proviene el niño que va a nacer y que curiosamente se llamará Sergio. Pero la obra no se encierra en estos límites, sino que contempla dos niveles más amplios: el social y el histórico. Precisamente por la naturaleza social de los sujetos, la obra trasciende el nivel familiar y se abre a una esfera mayor en la que aparecen otros actores que van conformando la imagen de una sociedad pequeña y dinámica, estructurada por individuos que cumplen una función muy importante en ella: el sastre, el repartidor de periódico, el tendero, el campanero, el telegrafista, el sacerdote, el zapatero, el teniente, el médico y los comerciantes ${ }^{12}$.

La inserción de la familia en el contexto social ha permitido que algunos críticos califiquen la obra como la historia de la familia, pero también como la historia del pueblo de Masatepe, donde nace el autor:

En el fondo, Un baile de máscaras es una historia más grande, la de Masatepe, la de sus pintorescos personajes, para los cuales el autor otorga un color y un calor que los hace completamente familiares y cercanos (Starcevic 1995: 2B) $)^{13}$.

La relevancia otorgada al mundo familiar y social parece ocultar el nivel histórico, que funciona como telón de fondo, aunque el autor no haga explícita su intención de ahondar en 
él, intención que se mantiene en todas sus obras y es como una llama que no se extingue y cada vez abarca nuevos temas. En este libro, Anastasio Somoza ya se ha convertido en dictador, y su poder es absoluto e indiscutible, porque es el único capaz de decidir ante situaciones particulares, como conceder un permiso para transportar un muerto de una ciudad a otra, liberar un preso o firmar una determinada orden. Pero el autor ha querido subrayar el hecho de que en 1936 derrocó a su tío Juan Bautista Sacasa de la presidencia, mediante un golpe de estado:

\begin{abstract}
Sucedió que en 1936, tras el golpe de estado con que el general Anastasio Somoza destronó a su tío el doctor Juan Bautista Sacasa de la presidencia, el doctor Macario Salamanca y tu tío Eulogio el violinista, que eran vecinos, correligionarios liberales, e íntimos amigos y compadres, cogieron cada uno su propio bando. El doctor Macario Salamanca del lado de Sacasa, asilado ya en la embajada de México, y tu tío Eulogio el violinista del lado de Somoza, dueño del palacio presidencial de la loma de Tiscapa.

Organizó cada uno, a los pocos días del golpe, su propia manifestación callejera, y fueron las manifestaciones, muy exaltadas y turbulentas, a desembocar al cruce de la calle donde vivían ambos, esquina de por medio. Se desataron primero los manifestantes en insultos y procacidades, hasta que llovieron las piedras y los garrotazos y se armó una trifulca que empeoró cuando el teniente Sócrates Chocano, al mando de tres únicos soldados de la Guardia Nacional acantonados en el pueblo, se presentó a reprimir a los sacasistas y a respaldar a los somocistas (131-2).
\end{abstract}

Cabe resaltar que las ambiciones políticas de Somoza habían quedado evidenciadas en el año 1934, cuando preparó el asesinato de Augusto César Sandino, quien había logrado la expulsión de los marines norteamericanos de su país. Víctor Bulmer Thomas (1993: 354), sintetiza, con las siguientes palabras, cómo se fraguó la dictadura somocista:

El asesinato de Sandino permitió al presidente Sacasa afianzar su autoridad en Nicaragua que aún funcionaba bajo un régimen constitucional. Sin embargo, los oficiales estadounidenses lo hicieron desistir de su intento por reemplazar a Somoza, su sobrino político, como dirigente de la Guardia Nacional, y así comenzó el país su lento y doloroso camino hacia una de las más largas dictaduras familiares jamás experimentada en América Latina ${ }^{14}$.

Aunque la obra no presenta un enfoque amplio del dictador Somoza, el autor se preocupa por subrayar su figura temible y el efecto que causa entre sus subordinados, tal y como lo refiere el narrador en el siguiente fragmento:

\footnotetext{
Las instrucciones militares de mantener preso a Ulises Barquero habían llegado directamente de Managua porque el propio general Macedonio Barquero, a instancias de su hermano don Salomón Barquero, lo había solicitado al Campo de Marte, y peor, la firma estampada en la orden telegráfica recibida por él, era la del mismísimo Tacho Somoza. Como sería de grave el asunto que don Vicente Noguera el telegrafista, al entregarle el telegrama la mano temblorosa, le había tenido que decir: perdóneme, teniente, que no es irrespeto mío, pero no vaya a romper la esquela al desdoblarla, que si se daña esa firma puede ser delito y sépase de una vez que yo se la entregué íntegra, sin ninguna rasgadura (Ramírez 1995: 148) ${ }^{15}$.
}

Un lector atento y conocedor de la situación política nicaragüense de los años treinta y cuarenta se interrogará por qué motivos tiembla el telegrafista y se asombra ante una firma que pareciera ser sagrada e intocable ${ }^{16}$. Este hecho demuestra, además, que el trasfondo histórico de la obra no es un puro ornamento o simple marco contextual, y su elaboración artística es bien particular, pues incluso alcanza un grado de humor, al mismo tiempo que se convierte en una crítica de mucha profundidad, que produce un efecto corrosivo y desestabilizador ${ }^{17}$ del poder político. 
La obra, además de novelar los inicios de la dictadura somocista, ofrece una mirada retrospectiva de la historia nicaragüense, mediante la alusión a hechos y personajes que han jugado un papel decisivo en la historia, efectuando, incluso, referencias a la conquista cuando describe a Saulo Regidor disfrazado de Francisco Hernández de Córdoba, el conquistador, barba postiza y gorguera al cuello, tal y como aparece en los billetes (p. 174) ${ }^{18}$ y abordando también el periodo correspondiente a los finales del siglo diecinueve y principios del veinte, para retomar la lucha entre liberales y conservadores. Esto último lo logra indicando que Emiliano Chamorro, jefe del partido conservador, dio varios golpes de estado y había efectuado una campaña contra el presidente liberal José Santos Zelaya (pp. 52-3) y señalando que el pueblo le rendía culto y adoración (pp. 88- 9) ${ }^{19}$.

También alude a la Revolución de 1926, la cual dejó serias consecuencias como la muerte de todos los cinco hijos de Deogracia Alvarado (p. 11) ${ }^{20}$ y tampoco falta alguna breve referencia a Sandino, que es aludido cuando el narrador cuenta que un hombre se disfrazó de Augusto César Sandino y el teniente Sócrates Chocano intentó apresarlo y se vio obligado a huir (p.161). Esto último lo hace en un tono humorístico y crítico que delata la persecución de que fue objeto dicho líder, en el contexto nicaragüense de comienzos del siglo veinte ${ }^{21}$.

La obra, además de referirse al contexto nacional, trae al presente lo que está ocurriendo en otras latitudes del mundo. Hay personajes que tratan de asemejarse a aquellos que tienen una connotación mundial. Así, el abuelo Teófilo viste como Josef Stalin y Domitilo Regidor "se trasquilaba el pelo y se dejaba una mosca por bigote como el führer Adolf Hitler" (p.160). Pero también se narra que Pedro le escribe cartas a Winston Churchill, que está muy ocupado con el problema de la guerra, especialmente contra los alemanes, los que constantemente hunden barcos de los aliados en el Atlántico. Además, Londres está siendo bombardeada a cada momento:

\footnotetext{
Ese retrato colgaba allí porque, a comienzos de ese mismo año de 1942, Pedro el tendero le había escrito a Winston Churchill una carta en nombre del Club de Leones de Masatepe, que acababa de ser fundado, felicitándolo por su defensa de la democracia, y solicitándole, a la vez, un retrato suyo autobiografiado, con su vidrio y su moldura.

Cuando se supo que la carta había sido despachada, porque cada cosa era de saberse y comentarse en Masatepe, hubo mucha diversión a costillas del remitente, empezando por sus tíos los músicos, que habían trasladado ya sus tertulias del atrio de la iglesia a la tienda recién abierta, qué saben en Inglaterra dónde queda Masatepe si aquí es el culo del mundo, qué caso va a hacerte Wisnton Churchill, va a romper y botar esa carta, como que estuviera desocupado para ordenar que te manden su retrato, y pedís poco, con vidrio y moldura, si además, ni tiempo de retratarse tiene, que no sabés que están bombardeando Londres día y noche, y ponele que lograra tomarse la foto y te la mandara firmada, los submarinos alemanes hunden a cada rato los barcos aliados en el Atlántico, preguntáselo si no a tu suegro don Teófilo, así que, de todos modos, nunca lograría atravesar el mar ese retrato (p. 82$)^{22}$
}

En la mayoría de estas referencias históricas, principalmente las relacionadas con el contexto mundial, no se nota un afán por crear polémica en torno a ellas, ni surge ningún artificio para ahondar en las particularidades históricas y psicológicas de los personajes referidos. Parecen referencias neutras ${ }^{23}$, pero están en la superficie textual y funcionan como núcleos generadores de sentido que enmarcan la narración en las coordenadas históricas y espaciales, de manera que el lector se informa de que el tema de la guerra es el asunto más preocupante del escenario mundial del momento. 


\section{Humor y transgresión de códigos}

El humor en toda obra literaria cumple una importante función apelativa: mantiene al lector atento y lo hace partícipe de las acciones narradas, pues provoca una respuesta activa que generalmente inicia con la risa. Por este motivo, el humor produce la catarsis, ya que propicia una reacción espontánea en la que el sujeto se libera de sus ataduras. Pero el efecto producido por el humor no se da en el vacío, ya que toda reacción humorística es intelectual y emocional $^{24}$ (Gruner 1997: 109) y, por lo tanto, implica una actitud reflexiva, basada en el tratamiento de los códigos imperantes en un entorno cultural.

De acuerdo con Lauro Zavala (1993: 14-5), el humor puede agruparse en tres grandes categorías: a) la que enfatiza las formas de incongruencia, b) la que se refiere a la hostilidad (superioridad, malicia o agresión) y c) la que considera el humor como un mecanismo de relajación ${ }^{25}$. Además, para el análisis de estas categorías es fundamental considerar que el humor se genera gracias a la existencia de una estructura binaria (en la que se oponen ciertos tópicos o códigos) y de un disparador semántico que se apoya en la ambigüedad o en el principio de la contradicción.

El autor, para lograr un efecto humorístico, parte entonces de oposiciones y tópicos culturales y políticos, característicos de una determinada sociedad, y les da un tratamiento literario que simultáneamente va produciendo un efecto lúdico y proyectando una visión crítica $(27-8)^{26}$, que es el resultado de su intención de transgredir normas y códigos sociales y que se plasma en el discurso y comportamiento de los personajes, según lo ha afirmado Umberto Eco (1989: 10) ${ }^{27}$ al sostener que el efecto cómico surge cuando los personajes desafían el poder represivo de las normas.

Por su parte, Elzbieta Sklodowska (1991: 84) considera que el humor es un recurso paródico y destaca que este nace de la incongruencia, la deformidad y la exageración ${ }^{28}$. Estos elementos aparecen dispersos en Un baile de máscaras y deconstruyen códigos sociales, morales y religiosos, con lo cual se desestabilizan los patrones culturales que han regido la sociedad. Entrar en esta obra es como sumergirse en una corriente de humor que va arrasando toda norma establecida, sin que surja en forma explícita una propuesta de cambio o modificación.

Lo primero que el autor muestra es un mundo poblado de personajes con algún "defecto" o particularidad física o psicológica, que trasciende los criterios de proporcionalidad y estética. Incluso, el mote o apodo recibido por ellos está en relación con sus rasgos o con su oficio $^{29}$. Así, a Tobías, por ser zapatero y salir de noche desnudo, lo llaman El Encuerado:

Así le había puesto Pedro el tendero, Tobías el Encuerado, no solo por su oficio de trabajar el cuero, sino porque ya borracho, y hastiado del jolgorio, salía desnudo en cueros y cuchillo de zapatero en mano a ahuyentar a los convidados de sus fiestas de vísperas del día del patrono de Masatepe, el Cristo Negro de la Santísima Trinidad (p. 22).

Inocencio recibe el calificativo de Nada porque su condición de albino lo hace prácticamente invisible:

Ya se sabe que al llegar el paquete en el tren de las cuatro recibe el periódico de manos de Inocencio Nada, un albino que de pies a cabeza parece bañado en leche, pelo, bigote, pestañas, cejas, como la cal, capaz de brillar en la noche oscura como un fanal de lumbre blanca; y si en el pueblo lo malnombran Nada, 
es porque así le puso Pedro el tendero quien inventa todos los apodos desde el mostrador de la tienda que tiene en su misma casa frente al parque, esquina opuesta a la Iglesia Parroquial: simplemente Nada, porque de tan blanco Inocencio Nada parecía no existir (p. 14).

Ireneo de la Oscurana es denominado así por el trabajo que realiza:

Mientras lee sin dejar de andar, no solo sufre distracciones a consecuencia de saludos, sino también de impertinencias, si es que así se las puede llamar, como esta vez la de Ireneo de la Oscurana el excavador de tumbas, pozos, excusados y botijas, que se tropieza con él, cegato todavía, porque viniendo de las profundidades de donde viene aún no se acostumbra a los fulgores del sol, y cubierto de tierra como fundido en cobre, así como Inocencio Nada parece bañado en cal (15).

Emiliano Chamorro es apodado el Cadejos por su capacidad de aparecer en cualquier sitio:

Aquel retrato enflorado es el retrato de Emiliano Chamorro, jefe supremo del partido conservador, llamado el Cadejo por el don de ubicuidad que tuvo en las batallas, capaz de presentarse en distintas trincheras al mismo tiempo; pues es ese Cadejo un perro embrujado que aparece y desaparece a su antojo, se materializa si quiere, y si quiere se borra de la vista; y, además, pero eso es aparte, se pone de noche en persecución de los adúlteros a la hora en que van o vienen de sus correrías (52-3).

A Eleuterio le dicen Eleuterio Malapalabra por su enorme pene, que parece una mano de santo y tiene una inscripción que dice "Recuerdo de una noche de amor en Constantinopla" (113) ${ }^{30}$; a Engracia la llaman La Guabina por tener sus ojos saltones, como un pescado que lleva su mismo nombre (38); a Macabeo Regidor lo apodan Vitriolo por su carácter retraído, hosco y difícil (40), Matilde y Clotilde Potosme son denominadas Las Gallinas Cluecas porque tienen una cantina del mismo nombre y además, abusan de Camilo:

\footnotetext{
Pero entonces, la Mercedes Alborada, al saberlo de regreso, lo buscó arrepentida, lo amparó, lo curó y lo quiso al fin; y tras ampararlo, cuidarlo y quererlo, fue que vino la madre de las hechiceras, la Dioclesiana Putoya a entregarlo en las brazos de la Gallinas Cluecas, las hermanas Matilde y Clotilde que lo usan sin darle tregua, ya se sabe en qué $(36)^{31}$.
}

Nótese que los rasgos físicos apuntan hacia la desproporción, mientras que los psicológicos representan características muy particulares y encarnan la violación de alguna norma moral. Aún hay más situaciones que hacen extrema esa ruptura por el grado de exageración alcanzado e igualmente implican una transgresión de códigos y sobrepasan los límites de la racionalidad, como sucede con Camilo, que aprendió a volar y esto le servía principalmente para mirar a las mujeres desnudas cuando se bañaban (35) y con Perfecto Guerrero, que con su mente desequilibrada, sale por las tardes y ofrece vender cualquier cantidad de caballerías de mar a la persona que encuentre (53).

El humor también surge de lo ilógico e incongruente . Así, el padre Misael Lorenzano, supuestamente un hombre casto y fiel representante de los preceptos divinos, organiza un concurso de penes, participa en él y actúa como juez. Pero además, siente la tentación de acariciar los penes que debe medir con el metro:

\footnotetext{
Fue con íntimo respeto y sobrecogimiento que, acto seguido, el padre Misael Lorenzano, en su calidad de juez, desplegando el metro de carpintería, se dio a medir a la orgullosa, guardando la distancia para no provocarla en nada a desafueros, aunque triste de no poderla acariciar, porque ya se sabe que veía y medía, pero no tocaba, pues en lo uno estaba la debilidad, y en lo otro su fortaleza (113).
} 
Además de esta, son múltiples las acciones en las que el padre Misael Lorenzano es tomado como motivo de humor y de burla, pues sus actos no riman con la verdad y la pureza, y hasta se vio obligado a huir de unos indígenas que querían vengarse de él porque los engañó:

\begin{abstract}
Es que iniciaba apenas el padre Misael Lorenzano el primer misterio gozoso del santo rosario, subido al púlpito en forma de cáliz, cuando empezó a advertir, sin concederle mucha importancia, la inquietud de las beatas que se persignaban más de la cuenta mirando con los ojos fijos al altar donde no estaba en su camerino el cristo negro sino otro muy distinto, blanco sonrosado; y al quinto misterio, mientras seguía llevando el rosario con ojos entrecerrados, fue despertando de su sopor por la entrada de la gente de Nimboya, muy malencarada que rumoraba ya su inconformidad.

Al final del rezo se oía ya el reventar de cohetes y morteros del lado de Nimboya, alardes de pólvora de los que nada bueno se podía esperar. Volvió entonces, a toda prisa, a la sacristía; y cuando Camilo el campanero volador terminó de trancar las puertas, con mucho costo porque los díscolos no se querían salir, resolvieron ambos en el encierro, tras un parlamento muy sofocado, que era mejor para el padre Misael Lorenzano fugarse (213-4).
\end{abstract}

La forma súbita e inesperada como se resuelven algunos hechos es parte del humor. Generalmente, el procedimiento consiste en la inversión del sentido lógico o esperado por los lectores. Mercedes Alborada sentía halago y satisfacción cuando Camilo la veía desnuda en el baño, pero un día, en actitud de rechazo, le propinó una pedrada; La Guabina se le presenta a Macabeo Regidor desnuda y lo provoca; sin embargo, cuando se le acerca le canta: "Esto que ves aquí/ nunca lo vas a tener/ Esto que viste aquí/ Nunca lo vas a gozar/ No te lo voy a prestar/ prestar"; Santiago Mayor al no poder conseguir rápidamente el permiso para transportar a su esposa muerta, no se queda en el pueblo sino que decide viajar con ella en el tren, como si se tratara de un pasajero más, con la sorpresa de que esta resucita al ver tan lindo el paisaje ${ }^{33}$; el fakir, después de que Telémaco Regidor le robó a su esposa Zelmira, levanta su cabeza y pide de comer y beber, como si no le importara la afrenta de que ha sido objeto, y por último, el matrimonio de Saulo Regidor y Adelina se decidió como resultado de un accidente que les ocurrió en el excusado:

\begin{abstract}
A preguntas necias, oídos sordos. Llegó la dueña Clotilde viuda de Mantilla atraída por las voces de alarma que dio el general Paulino Chica, y llegaron tras ellos los tísicos que por primera vez reían, y animados opinaban, entre toses, sobre la forma más apropiada de proceder, hasta que no hubo más y llamaron a Josías el carpintero que vino con las herramientas a sacar los clavos y despegar las tablas de la caseta; y mientras sonaban los martillazos y caían las tablas, el general Paulino Chica iba transmitiéndole al hechor, sin dejarlo de apuntar con el revólver Colt de cañón largo, los requerimientos de la dueña Clotilde viuda de Mantilla: ¿se va a casar? Sí. ¿Mañana mismo? Sí. Y solo faltó que llamaran al padre Misael Lorenzano y ya desnudo de tablas el excusado les diera allí mismo la bendición nupcial, que a un tiro de piedra estaba la casa cural, patio de por medio con la pensión de los tísicos (174).
\end{abstract}

No ha habido ni un romance, ni una relación sentimental previa entre Saulo Regidor y Adelina, pero este incidente, ejemplo de transgresión de códigos morales y religiosos, marca definitivamente la vida de ambos personajes, pues se constituye en el motivo principal para que se decida su matrimonio, ya sea por imposición de Clotilde, por vergüenza, honor, obligación o conveniencia. Además, la descripción del hecho y la participación activa de los personajes como los tísicos, Paulino Chica y Josías le confieren dinamismo y plasticidad al texto, que culmina con un efecto humorístico.

Así como estos personajes han transgredido ciertos códigos, también son objeto de burla y ridículo. Igual le ocurre al abuelo Lisandro, quien tuvo un enfrentamiento con Ireneo el de la Oscurana. Don Lisandro le reclamó al segundo la parte que, según él, le correspondía de una 
supuesta botija encontrada. Después de grandes esfuerzos por sacarla, en los que participaban los hijos excavando y sacando tierra, lograron llevarla a casa. Tomaron las más estrictas medidas de seguridad para abrirla y, cuando parecía consumado el hallazgo que cambiaría la vida de la familia, se encontraron que únicamente contenía maíz tostado: era "el maíz que los indios le dejaban a los muertos para que comieran" (66). Todas las esperanzas y la avidez de poseer un tesoro de don Lisandro se frustran y son objeto de burla.

Los códigos seleccionados por el autor resultan claves para interpretar críticamente la rebeldía y la actitud picaresca de los habitantes de Masatepe. Las diversas situaciones, por negativas que parezcan, son motivo de risa y en el fondo delatan una sociedad en la que no siempre se respetan y cumplen los códigos que la rigen. Telémaco Regidor atenta contra el respeto y la dignidad del fakir al robarle la esposa ${ }^{34}$ y hasta las personas con ciertas limitaciones económicas se atreven a explotar y engañar a otras, en un afán desmedido por obtener el máximo de ganancias posible, dejando de ser personas justas y solidarias:

\footnotetext{
Su madre, Clotilde viuda de Mantilla, había llegado años atrás desde Granada a temperar porque enferma como andaba de los pulmones, la envió su médico a Masatepe en busca de clima benigno; y tanto le asentó el clima que se quedó a regentar una pensión para tísicos forasteros, pensión que estaba precisamente en la esquina frente a la tienda del beduino. Los tísicos y las tísicas salían por las mañanas, en pijamas y camisones, a asolearse al corredor, solos y tristes, sentados en las mecedoras o acodados en el barandal, y casi ni se pasaban palabra entre ellos cuando, tras el llamado de la campana, se sentaban a comer una sopa transparente de verse en ella y su ración de verduras cocidas (172).
}

En Un baile de máscaras, el humor ha invadido la obra como la gota de agua que se esparce sobre la superficie y no oculta ningún problema social, pues saca a la luz las alegrías, contradicciones y problemas de los habitantes de Masatepe. Ahora bien, Sergio Ramírez considera que el humor es básico en cualquier obra literaria y para toda persona resulta esencial saber burlarse de sí mismo. Esta es una herencia de su propia familia, de sus padres y tíos que eran músicos, como la ha expresado en sus libros Oficios compartidos y Mentiras verdaderas. Considera que su vena artística proviene en mucho de sus antepasados músicos, de quienes aprendió a crear y a inventar, pero sobre todo a asumir la vida con un sentido del humor:

\footnotetext{
Pero también velé las armas de mi escritura en la tienda de abarrotes de mi casa, en el centro de la rueda de conversación de mi padre, y de mis tíos, músicos todos, integrantes de la Orquesta Ramírez, quienes antes de subir las gradas de iglesia, al otro lado de la calle, para tocar en las funciones religiosas, gastaban las tardes comentando las vidas de los que acertaban, para su propia desgracia, a pasar frente de las puertas de la tienda, en cada transeúnte una historia escabrosa contada a carcajadas, riéndose de todo el mundo, pero riéndose sobre todo de ellos mismos, con lo cual aprendí desde temprano que el verdadero sentido del humor existe cuando uno es capaz de reírse de sí mismo. Y el humor, como toma de distancia, ha sido constante en mi escritura (Ramírez 1998: 66) ${ }^{35}$.
}

Esta toma de distancia del sujeto con respecto a sí mismo y al contexto en el que se produce la obra le ha permitido proyectar sobre el mundo narrado una visión aparentemente objetiva. Ninguna institución o persona se libra del dardo del humor. Así, la Iglesia católica, la moral familiar, el matrimonio y el sistema político son apuntados certeramente, no con una denuncia directa, sino exponiéndolas en su situación concreta. Ni la misma familia, orgullo del autor, ha quedado exenta de esa crítica; sus padres y abuelos, ya sea por sus aberraciones o transgresiones de los códigos sociales y morales, no se escapan de ser punto donde confluyen el humor y la burla. 


\section{Ironía y crítica social}

Como figura del discurso literario, la ironía desempeña una función clave en el proceso de decodificación de los signos y, por lo tanto, en la semiosis textual, con la particularidad de que exige un lector que esté dispuesto a realizar un ejercicio intelectual encaminado a descubrir los sentidos que no aparecen de un modo explícito ${ }^{36}$, sino encubiertos en una forma compleja.

Precisamente por el carácter encubierto de la ironía, el lector debe seguir un determinado procedimiento para descubrir finalmente el sentido que el autor ha querido imprimirle a las palabras y acciones de los personajes, sin afectar la dimensión connotativa de la obra. En primera instancia, el lector debe rechazar y trascender el significado literal, para luego intentar varias interpretaciones y elegir el significado o conjunto de significados que sean más coherentes con la intencionalidad del autor ${ }^{37}$, rasgo imprescindible para que se produzca el efecto irónico.

De acuerdo con Jonathan Titler, la ironía responde a la necesidad del autor de expresar situaciones conflictivas, no de un modo directo sino en forma disimulada ${ }^{38}$, lo cual se constituye también, utilizando las palabras de Pere Ballart, en una ingeniosa forma de "defamiliarización" de la obra, pues el lector se ve obligado a asumir una actitud de razonamiento en relación con los enunciados particulares y con la totalidad del texto. De ese modo, logra "naturalizar lo escrito" y le confiere una mayor validación estética a la obra (Ballart 1994: 450) 39 .

El principio generador de la ironía es la contradicción observada en el lenguaje mismo y en los actos de un determinado sujeto o grupo. El autor la expresa asumiendo una distancia para denunciar con toda libertad "escándalos invisibles" ${ }^{40}$, lógicamente en el marco de un determinado contexto histórico y cultural. Pero esta contradicción, también apuntada por Umberto Eco (1989: 14) ${ }^{41}$, se orienta hacia la percepción compleja de la realidad, no esquematizándola de manera simplista. Se trata más bien de un movimiento intelectual en el que se pone a prueba la capacidad del lector para descifrar el sentido de la obra ${ }^{42}$, según los planteamientos del autor.

Un baile de máscaras parte de la alegría que se vivirá ese día con motivo del baile de disfraces y propone el nacimiento de Sergio como el centro en el que se unen las familias Ramírez y Mercado, al tiempo que establece una genealogía que parte de los abuelos y tíos y se concreta en los padres Pedro y Luisa. Los Mercado provienen de una fe protestante; los Ramírez, en cambio, se distinguen por su catolicismo y por una vertiente artística y musical. Cada familia es caracterizada con cierto orgullo, pero ninguna escapa de la ironía que el autor ha tendido sobre su obra, ya que actúan y proponen modelos de conducta que ni ellos cumplen.

En esta obra, la ironía sirve para evidenciar una sociedad llena de contradicciones, en la que afloran a la superficie diversas críticas relacionadas con códigos como la sexualidad, la educación, la religión, el matrimonio y la xenofobia. Todo queda al descubierto porque en lugar de enmascarar el inevitable punto de ruptura, la ironía lo admite abiertamente, encuentra su origen en "esta fisura y construye un contrasistema sobre él. Serenamente oximorónica, la ironía armoniza lo solemne y lo lúdico, la literatura y el lenguaje, el ser y el mundo"(Titler 1990: 271 $)^{43}$. Los actos de los personajes los van desnudando sin que perciban las paradojas o contradicciones que encarnan. Generalmente interpelan, juzgan y valoran a los demás sin examinarse ellos mismos.

En el nivel familiar, los miembros se muestran como personas que gozan de una gran libertad, pero también queda al descubierto la mano tirante y represiva de los padres, quienes, 
queriendo ser muy comprensivos, actúan de manera despótica y causan el descontento de los hijos: así, la tía Victoria fue sometida al siguiente interrogatorio por parte de Teófilo y Luisa:

\begin{abstract}
¿conocés a esa señora que entró aquí? No. ¿Y al marido de ella? No. ¿Le escribiste cartas a un hombre? Sí. ¿Y le dedicaste fotografías? Sí. ¿Quién es ese hombre? No sé. ¿Quién es? Profesor de colegio. ¿Te da clases? Sí. ¿Clases de qué? No sé. ¿Clase de qué? De francés. ¿Sabías que ese hombre era casado? No. ¿Te has visto con él personalmente? Sí. ¿Adónde? En el aula. ¿Y fuera del aula? En el patio. ¿A qué horas? En el recreo. ¿Y fuera del colegio? No. ¿En ninguna otra parte? No. ¿Nunca has estado con él? No. ¿Y él te ha escrito cartas? Sí. ¿Cartas de enamorado? Sí. Cartas con versos en francés. ¿Y vos le has contestado? Sí. Cartas con versos también. ¿En francés? No, en español. ¿Le has dedicado fotografías? Sí. ¿Y esas dedicatorias eran también con versos? No, dedicatorias que yo inventé (24-5).
\end{abstract}

Las preguntas tan drásticas y tajantes atormentaban a la tía Victoria, quien sucesivamente iba dando respuestas que se contradecían, pero también tenían un tono altanero que desagradó a los padres. Ellos mismos la acusaron de asistir a clases solo para seducir hombres casados y la sentenciaron a no volver al colegio y dedicarse a la costura en la casa, para lo que le consiguieron un dedal y una aguja. Esta falta de comprensión y el castigo desproporcionado generó que la tía Victoria huyera de la casa, posiblemente a California, Estados Unidos. Este hecho devela un comportamiento machista y una prepotencia de los padres, ya que pretenden reducir a la mujer al espacio doméstico. Aún más, este machismo es tratado con una mayor ironía y humor cuando la mujer pasa a ser objeto o simple mercancía. Tadea, esposa de Jonatán Toribio, es apostada en el juego de la taba, pues a Jonatán se le acabó el dinero. Entre broma y risa la mujer adquiere un valor puramente material, ya que los hermanos Aníbal y Leónidas Wong, la aceptan y la ganan, aunque luego se decepcionan cuando la van a reclamar, pues estaba vieja y gorda, con ciertos avisos de declive, no con la juventud de la fotografía mostrada por el apostante:

Entró y puso la fotografía de su mujer Tadea Toribio sobre el tapete. Pero su fotografía de joven, cuando se había casado con ella, cuando era briosa de ancas, cuando se sentaba a orinar en cuclillas en el jardín y los criados varones se quedaban embelesados viendo brotar el chorro de oro de entre el promontorio de alabastro de sus nalgas. Y dijo: Juego a mi señora esposa, es todo lo que tengo (118).

Este machismo también se aprecia en los pleitos y las riñas entre los personajes, y hasta en el final de la novela con el nacimiento de Sergio. Téofilo Mercado, el hermano de Luisa, desea que sea varón. Este comportamiento es parte también de la forma como la familia y la sociedad ven el sexo. Pero en este aspecto, la obra también despeja el tabú sobre la homosexualidad, ya que la ironía y el humor con que se trata esta, no deja de ocultar el rechazo tan fuerte que la sociedad siente hacia los homosexuales. Eneas Razzetto es el personaje homosexual elegido como centro de la ironía ${ }^{44}$; sus conocimientos en agronomía le permiten ensalzar el trabajo de Teófilo Mercado como agricultor, y este, en un gesto de agradecimiento le preparó una fiesta, a la que invitó a muchas personas del pueblo, pero estas, al conocer su carácter de homosexual, se mostraron indiferentes y no asistieron:

Modales equívocos y extrañas maneras notó tu abuelo Teófilo en el agrónomo mientras departían solos, en espera de los convidados que nunca aparecieron; pero fue un extravío suyo el pensar que así se comportaba su homenajeado porque los italianos son melodiosos al hablar y pegajosos de trato, tal como se lo confesó después a tu abuela Luisa, que mientras más seria se ponía al oírlo, más escondía la risa (62). 
A la vez que se evidencia la actitud del pueblo hacia el italiano Razzetto, se descubre también la visión irónica que se despliega en torno al abuelo Teófilo, por haber interpretado ingenuamente los comportamientos de Eneas, como parte de las características culturales de este. Esta ironía se desvanece cuando el narrador directamente lo caracteriza como un mamplora y un pervertido (62) que se esconde con sus mancebos en los cipreses del parque. Por otro lado, surge en torno a Eneas un sentimiento de identificación o compasión, ya que en el cine, después de ser descubierto haciendo un acto inmoral (intentar tocar el sexo a otro hombre) recibe un fuerte golpe. El dolor es muy grande y tiene que callar como símbolo del silencio que deben mantener los homosexuales en una sociedad represiva. Eneas, en el fragmento de una canción que le ha traducido a Leopoldina resume muy bien su situación: "Todo es dicha, todo es fiesta, solo para mí no hay, no hay contento, y para colmo del tormento, tengo que disimular" (31). A la homosexualidad de Eneas Razzetto hay que agregarle el sentimiento xenofobo que aparece en la obra para intensificar la crítica o el dolor del personaje. Aunque en Masatepe todos parecen vivir felices y convivir alegremente, el extranjero aparece estigmatizado, y su condición sexual acentúa el rechazo.

Hay otros personajes extranjeros que se han integrado a la sociedad y que son vistos de una forma negativa. A los chinos Aníbal y Leónidas Wong se les acusa de sacar provecho ilícito de su condición de comerciantes. Tienen fama de tahúres y de ser tramposos en todo; participan de la corrupción moral al aceptar a Tadea Toribio como una apuesta y reclamarla luego (118). No obstante esto, Tadea crea una imagen llena de humor y de ironía cuando se refiere a los chinos con las siguientes palabras:

\footnotetext{
...llévenme, yo soy la apuesta que ustedes ganaron, dejo mi casa y a vivir con chinos se ha dicho, con los dos si quieren, está bien, me arrebiato, y si comen ajo y se orinan en la cama, no importa, luego van a ver que ya desnuda sigo siendo igual de lozana que en esa foto. A como era el mediodía que había salido en carrera huyendo del chilillo de Jonatán Toribio para agarrar por sus partes nobles al primero que pasara por la calle (120-1).
}

A pesar del tono humorístico que Tadea le imprime a su conversación con ellos, deja dudas sobre sus costumbres, ya que los considera asquerosos, de hábitos higiénicos inadecuados, pues son capaces hasta de comer ratones tiernos (120), con lo cual los desprestigia. Pero también el comerciante Josué Armagedón, judío jorobado que llegó a Nicaragua como agente comercial de la casa Lahmann \& Kempf es tratado como un individuo transgresor de las normas morales y religiosas de la población; quería corromper a las jóvenes del pueblo, especialmente a Aurora Cabestrán, a quien le propuso marcharse con él, pero su madre Castalia se opuso porque él pensaba llevársela de pueblo en pueblo, sin avisar el itinerario ni el día de regreso:

\footnotetext{
...por lo que se le dijo que no, Dios libre, de parte de su madre Castalia, viuda de Cabestrán, según consejo del padre Misael Lorenzano, quien fue del parecer que la intención de aquel judío jorobado, lépero, labioso, adulador, matrero, era gozarla y dejarla después perdida en algún lupanar (28).
}

Los calificativos con que se le designa son denigrantes y lo presentan como un ser despreciable. También al turco Abdel Mahmud se le toma como un sinvergüenza porque acostumbra a andar "esquilando quién sabe a quién con los precios de las telas de su baratillo ambulante, aunque las dé a fiado" (128). En fin, la mayoría de extranjeros aludidos en la novela se dedican a actividades comerciales y sacan provecho de estas en varios sentidos, no solo 
económico. La sociedad descrita los mira con ojos negativos, y con ellos no son hospitalarios ni bondadosos, más bien, se vuelven hoscos y desconfiados.

Esta xenofobia no nace en Un baile de máscaras, ya que en Castigo Divino está claramente planteada. A Flora Guardia, esposa de don Carmen, se le reprocha el hecho de ser costarricense, pero su vinculación con la alta burguesía leonesa hacía pasar este asunto relativamente desapercibido. En cambio, a Oliverio Castañeda se le tenía gran desconfianza por ser guatemalteco; en cada una de sus referencias y acusaciones salía a relucir este aspecto. Comparativamente con doña Flora, el rechazo es contundente y está marcado además por el hecho de que Oliverio constituía una víctima del sistema político y estaba marginado del poder económico.

En términos generales, la ironía funciona como arma de denuncia que deja huella en los sujetos interpelados, porque los golpea de forma negativa y los encara con la realidad por medio de "una pulsante verdad que solo se puede capturar en el momento de su extinción" 45 (Titler 1990: 264) . La acción de cada personaje está teñida o contaminada por una ironía que va envolviendo progresivamente la obra:

\footnotetext{
Esta novela está cubierta por una lluvia muy tenue de ironía. Las cosas que dicen los personajes yo las aprendí en mi infancia, en las conversaciones con mis tíos, expertos en zaherir al otro, en burlarse. Hay un dejo irónico y burlón en los episodios mágicos. Todo está teñido de ese humor que oía en las tertulias de mis padres y abuelos, todas las tardes, hablando con la gente (Dobles 1995: 1) ${ }^{46}$.
}

De acuerdo con la cita anterior, la ironía se convierte en un recurso para exponer a los personajes encerrados en sus propias incoherencias y para denunciar a las instituciones que representan. El padre Misael Lorenzano queda descalificado como autoridad religiosa, con lo cual también se lanza una severa crítica contra la Iglesia Católica; Teófilo Mercado es un embustero; el abuelo Lisandro esconde alguna aventura amorosa del pasado y Anastasio Somoza es una sombra extraña que personifica la maldad del poder político cuando debería representar el orden y el progreso.

En un plano superficial, la obra describe una sociedad dinámica, alegre y llena de picardía, donde la música, el baile de disfraces, el ambiente de las cantinas, la convivencia de las personas y el nacimiento de Sergio están narrados con un tono festivo; pero, en una dimensión más profunda, la obra revela una sociedad en la que se desestabilizan las normas morales y familiares; el poder político y el poder religioso son una farsa; la tolerancia y el respeto a la diferencia en aspectos como el sexo son una utopía; la justicia se busca y se impone al margen de la ley y priva el individualismo sobre la solidaridad. De este modo, la ironía se extiende desde los individuos hasta la sociedad entera y el lector, al reflexionar sobre los hechos, solo percibe una imagen poco grata y muy crítica de esa sociedad.

Merece la pena destacar que la escritura irónica no es un rasgo totalmente nuevo en Un baile de máscaras, pues Sergio Ramírez ya lo había iniciado en Castigo Divino:

Castigo Divino represents a considerable shift in style and tone from Ramírez's previous novel. The passion of the writer opposed to dictatorship has been replaced bay the calculet irony of the politician who has asumed a position of power. The enemy may remain the same, but the balance of forces has shifted. The writer and politician not only can allow himself to use comedy, but is almost forced to do so. The tragedy is over (Ross 1991: 174$)^{47}$. 
Ross limita sus observaciones a la oposición que el autor había mantenido con respecto a la dictadura somocista, en otras obras suyas como ¿Te dio miedo la sangre? Encuentra que el hecho de haber pasado al poder le ha permitido tratar con mayor libertad el tema político. En Un baile de máscaras, ha llevado a significativos niveles de elaboración artística temas más amplios, cuyo rasgo común es el humor, en nada exento de la ironía y la crítica. Así como el humor ha representado una toma de distancia, el empleo de la ironía repercute en una desfamiliarización de la obra, con lo que el autor crea un espacio entre la obra y el lector, y entre la obra y él mismo, de tal modo que la percepción de la realidad resulta más objetiva y crítica.

\section{La expresión carnavalesca de la realidad}

El autor logra una expresión carnavalesca de la realidad mediante la instauración de una lógica de la contradicción, la parodia de códigos y el juego entre la realidad y la máscara, lo que, al mismo tiempo, le permite trascender las relaciones de exclusión social, política e ideológica y proponer la novela como un espacio abierto en el que es posible la convivencia de visiones del mundo opuestas entre sí. Se tiende más a la integración y conciliación de elementos para otorgarle a cada personaje una voz particular en la esfera social en la que ocurren los hechos.

La obra está estructurada de manera que se superan las diferencias entre los personajes y se confunden los tonos. Macabeo Regidor se suicida y es velado en casa de las hechiceras y con la imagen del Cristo de la Santísima Trinidad, hecho que sorprende la mentalidad religiosa del pueblo. Incluso la posición de rechazo hacia los norteamericanos, tan evidente en obras anteriores, aparece matizada y más bien se proyecta una valoración relativamente positiva de ellos al resaltar que en el campo de la educación imponen una disciplina estricta y rígida:

\footnotetext{
No les había parecido que la hija, la primera mujer que obtenía un título de bachiller en ciencias y letras en la historia del pueblo, graduada tras un internado de cinco años en el Colegio Bautista de Managua, un colegio de yanquis protestantes, rectos y severos de nunca probar licor ni fumar, se casara con quien viniendo de una familia de filarmónicos no tenía bienes de fortuna, o sea y mejor dicho, ni donde caer muerto (63).
}

Esta forma de presentar los hechos responde a una nueva concepción de la realidad, en la que las cosas no son vistas en términos tajantes y absolutos y las múltiples contradicciones que aparecen en la novela encarnan una visión crítica y paródica de las normas sociales.

Son frecuentes las yuxtaposiciones de actividades y acontecimientos que encierran sentidos opuestos. El dolor y la alegría coinciden en un mismo personaje: Saulo Regidor sufre por el suicidio de su hermano Macabeo, pero no interrumpe el baile de disfraces: "Mientras Saulo Regidor el teñidor de trapos seguía moviendo los brazos en actitud de dirigir la orquesta, y lloraba con un solo ojo, empezó de nuevo a tronar en amenaza inminente de otro aguacero" (180). Justamente en ese mismo instante, el tío Edelmiro, al escuchar esta noticia e imaginarse lo trágica que ha sido la muerte, cae desmayado y se interrumpe la música (182), además el viento se lleva las partituras e inicia un aguacero como un diluvio. Pero no solo se trata de la coincidencia de estos sentimientos, porque, en otro personaje como Juan Castil, se encuentran representadas sintéticamente la bondad y la maldad. Es llamado el ladrón ratero sin redención porque frecuentemente lo encarcelaban y no se corregía y, además, había representado en una oportunidad a Jesús de Nazareth, en una función organizada por el padre Misael Lorenzano: 


\begin{abstract}
Sin necesidad de preguntárselo supo que no iba al baile representando a un procónsul romano cualquiera, sino al mismo Poncio Pilatos, porque camino a la covacha había visto a Juan Castil el ladrón ratero sin redención, eterno reo de confianza, vestido de criado romano, ocupado en pulir una bandeja de electroplata, una jofaina y una ánfora del mismo metal. Disfraz muy rebajado ese, el de criado de Poncio Pilatos, si se piensa que en un tiempo hizo el papel de Jesús de Nazareth en la Judea del padre Misael Lorenzano (147).
\end{abstract}

También, en un mismo día, se superponen actividades muy diferentes: la boda de la tía Adelfa, el entierro de Diocleciana Putoya, el suicidio de Macabeo Regidor y el baile de disfraces, como se desprende de esta descripción que efectúa el narrador sobre las actividades de Pedro ese día:

\footnotetext{
Se pone, otra vez, ya se dijo, la leva, y se quita el azahar que aún lleva en el ojal de la solapa, pues con ese mismo traje asistió por la mañana al casamiento de tu tía Adelfa: una boda, un entierro ese día; más tarde, un baile de disfraces $(37)^{48}$.
}

La contradicción y la ambigüedad van cobrando vida en la novela y terminan por imponerse como lógica narrativa, pues se pasa fluidamente de un suceso violento o luctuoso a otro festivo, como el cumpleaños, la boda o el baile.

El humor y la ironía que aparecen a lo largo del universo narrativo de Un baile de máscaras constituyen dos importantes recursos para abordar distintos códigos e instituciones desde una perspectiva crítica. Sustituyen la denuncia directa y crean una distancia tal que el lector encuentra múltiples situaciones yuxtapuestas, las cuales debe valorar según su competencia cultural. Además, producen la sensación de estar ante un juego en el que concurren y se confunden distintas voces. Este juego representa la expresión de la realidad de una forma carnavalesca, cuya condición indispensable es, según Umberto Eco (1989: 16), la parodia de las reglas y los rituales que han sido tomados como norma y respetados en una determinada sociedad $^{49}$. La novela cumple con este punto de partida y, mediante una serie de inversiones semánticas ${ }^{50}$, apunta hacia la parodia y destrucción de las jerarquías.

La solemnidad con que se caracterizan los espacios sagrados es derribada por los comportamientos del padre Misael Lorenzano. Irónicamente, nunca llega a encarnar la moral y la fe que su Iglesia debe promover y se constituye en el principal profanador de los mandatos cristianos al participar en actos obscenos y corruptos. Su misión se desvirtúa y pasa a convertirse en un individuo común y corriente, capaz de ocultar su identidad como religioso para cometer algunas fechorías o para librarse de quienes lo persiguen. Paradójicamente, defiende y profana los espacios sagrados, eleva a Jesucristo a la categoría de verdad absoluta, pero también lo vulgariza al presentarlo en un sermón como un boxeador que se enfrenta a Quevedo, un personaje satánico.

Este sermón no pretende adoctrinar, ya que en él aparecen lo vulgar y lo mediocre; tampoco se observa una intención de lograr una transformación sustancial de los feligreses, con lo cual no se cumple el fin de enseñanza de la buena doctrina, como tradicionalmente se ha entendido el sermón en el marco discursivo de la religión católica. Es así como la parodia se produce al abrirle un espacio a un tema vano y vulgar como es una pelea de boxeo. Ramírez empieza titulando el discurso del padre Misael Lorenzano como "Sermón del padre Misael Lorenzano acerca del match de boxeo entre Quevedo y Jesucristo", lo que le da una connotación paródica; pero, en realidad, la parodia empieza desde las páginas anteriores, en las 
que se ha puesto en duda la autoridad moral y religiosa del padre Lorenzano y luego esto se acentúa al utilizarlo para mostrar la profanación del espacio sagrado:

\begin{abstract}
Lucas Velero, en cargo de su miserable papel de second, esperaba ya a su compinche en una esquina del altar mayor, el balde en la mano y la toalla al hombro; y apenas se vieron y reconocieron, se entregaron entre ellos dos a un jolgorio de saludos jayanes, chistes obscenos y risotadas vulgares, como es costumbre entre malandrines, apartándose luego a planear en secreto sus tácticas criminales, mientras tanto se desnudaba Quevedo de su capa, jubón y calzas para quedarse en calzoneta impúdica de boxeador. Y aquel otro que les he dicho, Lucas Velero, que se avergüence ahora, le amarraba los guantes.

Me fui a la esquina de Jesucristo, a quien encontré triste y abatido por los pecados del mundo [...] Si al fin aceptó calzarse los guantes, porque ni sabía que se necesitaba guantes para una pelea de boxeo, fue debido a mis muchas súplicas. Y luego, entre round y round, sépanlo, no habría de aceptar agua para su sed, sino vinagre y hiel (124-5).
\end{abstract}

En el sermón que pronuncia, exalta virtudes de Jesucristo, como poner de nuevo la mejilla cada vez que recibía un estrepitoso golpe de Quevedo; pero, en términos generales, el autor juega con la imagen divina: Jesucristo baja de lo alto no para ofrecer una lección moral, sino para que el público disfrute. Incluso, mientras el padre da el sermón, los asistentes cuentan chistes obscenos, explotan en risotadas vulgares y hacen un completo jolgorio (125-6).

Como puede notarse, no solo se profanan los espacios sagrados, sino que la figura grandiosa de Jesucristo es rebajada a la de un boxeador. Así, Ramírez desacraliza uno de los mode$\operatorname{los}^{51}$ e instituciones más importantes e intocables de la historia nicaragüense y latinoamericana.

Por otra parte, el autor se sirve de la máscara como uno de los principales medios para configurar la realidad de un modo carnavalesco. No se reduce a baile de disfraces, que de todas maneras no se realiza a plenitud. La obra en sí constituye un baile de máscaras, pues las acciones y los movimientos de los personajes apuntan hacia un juego con la identidad. El sentido primario del disfraz, que es participar de la alegría desbordante en casa de Saulo Regidor, se cumple a medias. Algunos personajes se disfrazan de otros como Azucena de Scarlett O’Hara, Sócrates Chocano de Poncio Pilatos (42), Amantina Flores y Telémaco Regidor de Luzbela y Luzbel, respectivamente (200) y con ello logran importantes dosis de humor dentro de la novela. Además de generar ludismo y catarsis, el verdadero sentido que alcanza la máscara en la novela es el de ocultar una identidad para alcanzar determinados fines, o para ironizar sobre un personaje. Así, Pedro irá vestido de beduino al baile de disfraces para no ser reconocido por Telémaco Regidor y ajustar cuentas con él, obligarlo a casarse (30), y el padre Misael Lorenzano se disfraza de la Virgen Dolorosa de los Siete Puñales, para esconderse de unos indios que le reclaman mayores actos de fidelidad, verdad y voluntad (213).

La máscara le permite al sujeto permanecer inocente, pecar y ocultar cualquier infracción; crea una distancia y bloquea la posibilidad de ser conocido realmente (Rodríguez Monegal 1979: 402). Al igual que Pedro y el padre Misael Lorenzano, quienes se esconden tras la máscara para lograr sus cometidos, personajes como la tía Leopoldina la utiliza para encubrir su embarazo que representa una transgresión a las normas morales. Disfrazada de Ana Bolena, con traje holgado, nadie la reconocería (166). Pero también se llega a situaciones muy especiales en las que la máscara y la realidad se confunden, como le sucede a un individuo que pretendía representar a Quasimodo pero no lo premian porque realmente era jorobado (161) y como le ocurrió a la misma tía Leopoldina y a Telémaco, quienes, en una representación teatral, debían simular un beso y se lo dieron de manera muy intensa y prolongada: 


\begin{abstract}
Ese beso de amor, que no había logrado en los ensayos, la princesa Magalí Mahmud esperaba recibirlo hasta encenderle de verdad los labios, en pleno escenario. Y así ansiosa aguardaba su número, paseándose tras bambalinas, cuando descubrió que aquellos dos se besaban al amparo de los paraguas desplegados, y el beso, cómo habría sido, porque corrió la princesa arrastrando la cola de su manto de armiño, se detuvo en vilo la Orquesta Ramírez, apartó ella, furiosa, los paraguas de las caras de los bailarines, y se volvió hacia el público partida en llanto, señalando culpables con el índice a los que sin reparar en nada seguían besándose, un beso intenso y sin medida que nunca se volverá a repetir. Solo mucho rato después los aplausos frenéticos del público los despertaron de su letargo, y avergonzada tu tía Leopoldina, que él era un descarado, hubo de utilizar su paraguas para esconderse de nuevo mientras el telón, coleando, subía y volvía a bajar $(59)^{53}$.
\end{abstract}

Sea mediante la lógica de la contradicción, la parodia o la máscara, Ramírez orienta su obra a la destrucción de diversos centros vinculados a alguna forma del poder. Para Emir Rodríguez Monegal (1979: 206), esta acción representa una estrategia carnavalesca ${ }^{54}$ en la que los personajes se integran y confunden. En este sentido, el autor apuesta por la unión de los contrarios, pues encuentra que en esa no disyunción ${ }^{55}$ se definen las características esenciales de la sociedad descrita.

\title{
7. A modo de conclusión: más allá del juego
}

Como novela que expresa la realidad a partir de un juego de contradicciones, Un baile de máscaras pareciera distanciarse de la realidad conflictiva y problemática que ha enfrentado Nicaragua en el siglo veinte, especialmente en la segunda mitad. Pero lo que ha cambiado es la perspectiva desde la cual el autor trata esa realidad, así como los recursos empleados. En realidad, la obra recupera la cultura popular festiva de Masatepe mediante diversos juegos de humor, ironía y parodia que desembocan en una risa iluminadora de la realidad social ${ }^{56}$. A final de cuentas, es una 'risa seria', ya que de ella se desprende una visión particular de diversos elementos personales, sociales, culturales, históricos y políticos, que han sido puestos en contacto y confrontados para desenmascarar las formas del poder y los vicios que pretenden implantarse como absolutos en dicha sociedad.

Ramírez recrea el microcosmos del pueblo de Masatepe, pero el enfoque realizado le permite superar la vertiente vernácula y regionalista de sus obras iniciales ${ }^{57}$, a pesar de que en ella aparecen elementos costumbristas y pintorescos. Además de desvelar los puntos álgidos de la sociedad, para que el lector interprete y juzgue, la narración adquiere matices universales:

\footnotetext{
Lo que cuenta, aunque ocurra en lo más hondo del Masatepe que lo vio nacer, es completamente universal. Con la mayor soltura, teje la trama de su novela pasando de una historia individual a la otra, sin que corte el hilo narrativo; por el contrario, cada historia individual agrega algo nuevo, una pista a la intriga que es el eje de ese día (Starcevic 1995: 2B $)^{58}$.
}

En un ámbito más amplio, la obra reelabora el sabor propio de un pueblo latinoamericano, pero no pretende una lectura inocente y lineal. La referencialidad geográfica es específica pero los temas tratados como el amor, el honor, la traición y el poder adquieren una connotación universal, sobre todo si van acompañados de la risa ${ }^{59}$, la cual siempre ha sido un rasgo de universalidad.

Por otro lado, merece la pena recordar que la novela fue escrita en 1995, en un momento en el que reina la confusión y las percepciones exclusivas de la realidad han empezado 
a desmoronarse. Ramírez vuelve su mirada a la década de los cuarenta y encuentra que, a pesar de los múltiples problemas que había, él es producto de una interesante síntesis de diferentes formas de percibir la realidad. Se declara hijo de una visión del mundo en la cual se trascienden los maniqueísmos y coexisten formas contrapuestas de entender la vida. Asimismo, encuentra que sus raíces están llenas de un espíritu picaresco ${ }^{60}$ y burlón, pues sus familiares, como todo el pueblo, aprendieron a reírse de los demás y de ellos mismos, llegando a afirmar, incluso, que su oficio de escritor se nutre de dos vertientes que corrían por separado, pero terminan juntándose:

\footnotetext{
Imaginación y razón. Ficción y realidad. Mis dos abuelos inventores, cada uno en su vena, de allí es de donde vengo; la ambición de transformar el mundo, cambiar la realidad, ya volveré sobre eso. Pero también una herencia de equilibrio que nunca me ha abandonado, no en balde soy fruto del amor entre mi padre católico y mi madre protestante. Ambos supieron zanjar sus diferencias religiosas, acomodar sus creencias y establecer la paz y la estabilidad domésticas, terminando por convertirse, gracias a un armisticio tácito, en agnósticos practicantes. Como hijo de la tolerancia, me siento obligado a ella (Ramírez 1994: 67-8) ${ }^{61}$.
}

Ramírez, en primera instancia, acentúa la vertiente racional y pragmática de su abuelo Teófilo Mercado y la imaginaria en la familia de su abuelo Lisandro Ramírez. Sin embargo, en el contacto cotidiano, estas familias aprendieron a convivir y a compartir muchos de los aspectos de la vida social, principalmente mediante la integración que significó el matrimonio de sus padres, ejemplo concreto de cómo se logran compenetrar personas de ideas diferentes. Por otra parte, aunque la novela estrictamente no corresponde al género biográfico, le ha permitido al autor reflexionar sobre su propio origen y encontrar en él las bases de su vida y de su trayectoria como político y escritor ${ }^{62}$. Es, además, la primera vez que, desde el ámbito literario y en forma explícita, reconoce la importancia de asumir la realidad desde una perspectiva múltiple, en la que se recupera la voz del otro y se integra a la dinámica histórica y cultural sin ningún matiz de marginación. Humor, ironía, parodia y carnaval son las estrategias discursivas que hacen emerger esta nueva concepción de la realidad y de la escritura también, basada en la síntesis y confluencia de los contrarios.

Un baile de máscaras representa una especie de liberación del autor de las ataduras ideológicas que lo habían marcado en sus novelas anteriores al triunfo de la Revolución Sandinista. Esto le resulta fundamental para expresar la realidad de una forma carnavalesca y sobre todo para, como dice Umberto Eco (1989: 11-2), "coronar la multitud" 63 que se siente libre del peso de las jerarquías y de los absolutos. La forma irónica y burlesca con que trata los temas de carácter histórico y político y el adentrarse en un universo más personal y familiar produce una narrativa muy fluida, en la cual la crítica no nace de la denuncia certera, sino de la risa que amenaza, parodia y pone en entredicho las jerarquías que han regido el orden social. En apariencia, el mundo narrado es un cuadro lúdico, pero como obra irónica, Un baile de máscaras proyecta una visión del mundo paradójica y conflictiva.

\section{Notas}

1. Ya en esta novela el autor se refiere al tema de las personas que se formaron fuera del país, principalmente en Francia, asunto que volverá a aparecer en Castigo Divino, con el Doctor Darbishire. En las siguientes citas de las obras de Sergio Ramírez, solo se indica el número de página entre paréntesis. Los demás datos corresponden a las ediciones citadas en la bibliografía. 
2. El autor utiliza el tema del incesto para darle un tono humorístico e irónico a la narración. Recuérdese que este tema ya lo había tratado Gabriel García Márquez en Cien años de soledad (1967), con la diferencia de que en la novela de García Márquez se constituye en un tormento y en una maldición para la estirpe de los Buendía.

3. Este fragmento corresponde al artículo 64 del último de los textos que integran el libro: "Suprema ley por la que se regula el bien general de las personas, se premian sus acciones nobles y se castigan sus actos y hábitos, dictada en XIV parágrafos". Véase: Ramírez, Sergio (1973): De tropeles y tropelías. 1973: 78. Las siguientes citas de esta obra solo se harán indicando el número de página entre paréntesis; los demás datos corresponden a esta edición.

4. En su ensayo "El escritor centroamericano" (en Texto crítico, Año X, núm. 29. 1984: 74), Sergio Ramírez considera que utilizar la fábula, desde el punto de vista literario, ofrece ventajas porque permite la expresión de situaciones políticas e ideológicas complejas, y además, se logra evadir la censura del poder, tan determinante en el ámbito centroamericano.

5. Febles apunta que la concepción de la obra como juego puede observarse también en el tratamiento literario que le da el autor al beisbol.

6. Este burdel ha sido calificado por E. San Juan, como un espacio casi legendario. Véase: San Juan, E. 1989-1990. "History, textuality and revolution. En Likha. Vol. 11, núm. 2, pp. 52 y 61.

7. En el burdel de la Sinventura, los personajes encuentran el espacio propicio para expresar libremente sus ideas y emociones, sin preocuparse por las normas sociales y las imposiciones políticas. En otras partes de la obra, este ambiente de libertad abarca también temas de carácter histórico y cultural. Véanse las páginas $85,113,140$ y 235 .

8. Estos versos pertenecen al texto "Little Gidding" y han sido traducidos por Esteban Pujols Gesalí, de la siguiente manera: " y el fin de nuestra búsqueda será/ llegar adonde comenzamos/ y el lugar conocer por primera vez”. Véase: Eliot, T.S.: Cuatro cuartetos, Edición bilingüe de Esteban Pujols Gesalí, Traducción Esteban Pujols Gesalí, Madrid, Ediciones Cátedra, 1987, pp. 158-159. En otros versos anteriores a estos, Eliot expresa: "What we call the begining is often the end/ and to make an end is to make a begining/ the end is where we star from" (Lo que llamamos comienzo a menudo es final/y llegar a un final es empezar/ El fin es de donde partimos), con lo cual, la idea de retorno al principio, la niñez para Sergio Ramírez, se torna fundamental para la exploración de la existencia. Por otro lado, Gioconda Belli (2001: 406), en su libro El país bajo mi piel, utiliza estos mismos versos citados por Ramírez para aludir a su experiencia vital en los Estados Unidos, donde después de sentirse sola y exiliada en Washington y al trasladarse a vivir a Los Ángeles, sintió que, por el paisaje y la arquitectura de esta ciudad, era como volver a sus años de infancia en Managua.

9. Mora Rodríguez (1995: 13) agrega que el contraste entre las obras también puede notarse en el final de ambas: dramático en Castigo Divino y festivo en Un baile de máscaras.

10. Este carácter autobiográfico debe entenderse en términos relativos, pues la obra nos permite conocer más la familia que al propio autor (desdoblado en el personaje Sergio), ya que el lector apenas asiste al día de su nacimiento.

11. Nótese que a pesar del carácter autobiográfico y referencial de la obra, la ficción termina imponiéndose como parte del proceso creativo.

12. En la novela también aparecen otros personajes que generan un ambiente muy particular a la narración: el mago o adivino, las hechiceras, los músicos y los tahúres. 
13. Starcevic limita su apreciación a la historia de Masatepe, pero en realidad la obra remite a coordenadas más amplias, de ahí la alusión a hechos y personajes de la historia nicaragüense.

14. Ángel San Juan agrega que la dictadura somocista se caracterizó también por infringir en forma sistemática las normas electorales. Véase: San Juan Marciel, Ángel. 1988. Diagnóstico sociológico de doce comunidades nicaragüenses. Madrid: Universidad Complutense de Madrid: p. 56.

15. Las siguientes citas de esta obra se harán indicando el número de página entre paréntesis. Todos los demás datos corresponden a esta edición.

16. Según Víctor Bulmer Thomas (1993: 384), la represión implantada por Somoza estaba en función de "mantener a la población en su lugar".

17. María Caballero (1993: 155-6), al referirse a la obra de René Marqués, sostiene que el humor es una arma letal para luchar contra el sistema y en la narrativa hispanoamericana contemporánea sustituye la denuncia de tono panfletario.

18. Francisco Hernández de Córdoba inició la colonización española en Nicaragua en 1523 y ya en 1524 estableció las primeras encomiendas en las poblaciones de Granada y León. Véase: Kraner, Wendy; Lovel, George y Lutz, Christopher. 1993. "La conquista española en Centroamérica”. En Pinto Soria, Julio (editor). Historia general de Centroamérica, Tomo II. Madrid: FLACSO, Sociedad Estatal Quinto Centenario: pp. 24, 26, 28 y 36.

19. José Santos Zelaya, de ideología liberal, llegó al poder el 25 de julio de 1893 mediante una invasión armada y fue forzado a dimitir por presión de los Estados Unidos el 18 de diciembre de 1909. Emiliano Chamorro, de ideología conservadora, estuvo dos veces en la presidencia. La primera fue nombrado mediante elecciones, el 1 de enero de 1917 y gobernó hasta el 31 de diciembre de 1920; la segunda llegó al poder mediante un golpe de estado, el 16 de enero de 1926 y renunció el 30 de octubre del mismo año. Consúltese: Bulmer Thomas, Víctor. 1993: pp. 363, 409-410.

20. La novela alude al golpe de estado que el conservador Emiliano Chamorro dio al presidente Carlos Solórzano, que estaba en el poder desde el 1 de enero de 1925. Chamorro gobernó desde el 16 de enero de 1926 hasta el 30 de octubre del mismo año. (También había gobernado desde el 1 de enero de 1917 hasta el 31 de diciembre de 1920). Consúltese: Taracena Arriola, Arturo 1993: 239

21. Augusto César Sandino nació en 1895 en Niquinohomo, Masaya. Desde muy joven se perfiló como el líder y ya en el año 1927 creó el Ejército Defensor de la Soberanía Nacional con el fin de proteger a Nicaragua del imperialismo norteamericano y de las clases dominantes que estaban aliadas con el primero. Muy pronto se convirtió en un ejemplo de liberación no solo para Nicaragua, sino para toda América Latina y ello le ocasionó una persecución y serios enfrentamientos que culminaron con su muerte en el año 1934. Sergio Ramírez, en su libro Sandino (San José, Costa Rica, Ministerio de Cultura, Juventud y Deportes. 1978) efectúa una interesante aproximación biográfica e histórica a este personaje.

22. La obra revela parcialmente el eco que tuvo la Segunda Guerra Mundial en Nicaragua. A pesar de lo trágico que se le presentaba la situación, Churchill efectivamente le envió el retrato a Pedro el tendero.

23. En la obra literaria no existe ningún componente estructural, lingüístico o temático que no tenga implicaciones semánticas e ideológicas.

24. Esta afirmación de Gruner revela que el efecto humorístico se logra gracias a la intencionalidad del autor, que ha escogido una retórica específica para expresar determinadas ideas, pero también exige un esfuerzo del lector para decodificarlas. 
25. Según Zavala, la categoría referida a la hostilidad permite abordar las relaciones entre el autor y el lector; la de relajación se centra en el aspecto psicológico del lector y la de incongruencia puede abordarse fundamentalmente en la obra.

26. Entre las principales oposiciones binarias que llevan a un efecto humorístico están: lo normal/lo anormal, lo posible/lo imposible, bien/mal, joven/viejo, sexo/no sexo, alto/bajo. Estas oposiciones pueden ampliarse y deben responder a una realidad cultural específica; además, deben ser consecuentes con la intencionalidad del autor de darle un tratamiento específico a ciertos temas.

27. Eco atribuye un notable poder subversivo al humor.

28. Para Sklodowska, el humor representa una intención de dar un tratamiento particular a ciertos códigos, pues la incongruencia, la deformidad y la exageración están en relación con determinados modelos o tópicos sociales y culturales.

29. Según Arnoldo Mora Rodríguez (1995: 13), el apodo le quita los elementos dramáticos a los personajes y provoca la sonrisa cómplice del lector.

30. Esta referencia al tamaño del pene de Eleuterio Malapalabra recuerda al José Arcadio Buendía de Cien años de soledad, cuyo sexo desmedido parecía "un animal en reposo". Véase: García Márquez, Gabriel. 1967. Cien años de soledad. Madrid: Cátedra; p. 119. Además, estas escenas de humor se fundamentan en oposiciones binarias referidas al tamaño (pequeño/grande) y en la utilización del sexo como un tópico cultural.

31. Nótese cómo el autor ha preferido darle un tono de intriga al texto; sin embargo, el sentido es suficientemente claro si se tienen en cuenta todas las acciones de estos personajes. En la novela hay, además, otros personajes que no reciben ningún apodo pero sí son frecuentes las alusiones a su físico desproporcionado, como Adelina Mantilla, la gorda más gorda y Zelmira, la esposa del fakir, que es muy delgada, pero de pechos protuberantes en exceso.

32. Esta construcción del humor a partir de lo ilógico e incongruente se observa con claridad en la novela El amor en los tiempos del cólera de Gabriel García Márquez, como sucede en la escena donde la Viuda de Nazareth, después de tener relaciones sexuales con Florentino Ariza, le dice: "Te adoro porque me volviste puta”. Véase: García Márquez, Gabriel. 1985. El amor en los tiempos del cólera. Bogotá: Editorial Oveja Negra; p. 50.

33. En este caso específico, el autor también recurre a la hipérbole como una forma de acentuar más el tono humorístico de la obra.

34. Incluso, este acto se consuma como el resultado de una apuesta que había hecho con Ulises Barquero.

35. En Mentiras verdaderas (2001: 41) el autor insiste en la importancia del humor como toma de distancia ante el universo narrado y reitera que "El humor solo es verdadero, no lo olvidemos, cuando uno es capaz de reírse de uno mismo".

36. Wayne Booth se refiere a la participación del lector en un proceso de reconstrucción del sentido que lo lleva a descubrir "una conclusión manifiesta inaceptable" que luego será decodificada o transformada en una “conclusión encubierta aceptable". Véase: Wayne, Booth. 1986. Retórica de la ironía. Madrid: Taurus.

37. Los enunciados irónicos son creados por un sujeto para transmitir una determinada idea o imagen sobre un acontecimiento, un personaje u otros elementos de la realidad, de ahí que Booth considere la ironía como un hecho reflexivo más que accidental. Ibid., p. 30. 
38. Titler (1990: 17) también apunta que la ironía requiere un sujeto desligado de su situación y capaz de asumir una distancia ante lo narrado.

39. En este mismo sentido, Amalia Pulgarín considera que la ironía funciona como un importante filtro distanciador. Véase: Febles 1996: 158.

40. La ironía desnuda aquellos mecanismos ideológicos que tienden a presentar la realidad de un modo armónico y asume una particular forma de denuncia (Titler: 16).

41. Para Ana María Vigara (1994: 22), el humor implica una fina ironía que provoca una sonrisa interior y también una constante reflexión.

42. La posición de Booth (1986: 67) me parece más amplia que la de Umberto Eco, ya que considera que no se trata de un simple cambio o inversión de sentido, sino de un proceso donde "abandonamos un estrado y tanteamos otro más sólido".

43. Más que armonizar en términos literales, la ironía integra diversos aspectos de la realidad debido a que se construye como respuesta a determinados códigos o situaciones sociales.

44. Tradicionalmente se ha considerado que la ironía implica la existencia de una víctima, la cual puede ser un personaje o grupo social. Esta situación se presenta en Un baile de máscaras; sin embargo, Wayne Booth (1986: 57-8) considera que la ironía no siempre se plantea en estos términos, pues hay personajes que disfrutan de la ironía y no se sienten víctimas de ella.

45. La ironía en el momento de ser decodificada se extingue como tal y se convierte en el enunciado correspondiente a la "conclusión encubierta aceptable" de que habla Wayne Booth.

46. Nótese que el autor asigna al humor y a la ironía un valor referencial, porque según él los aprendió de su familia. Sin embargo, no debe olvidarse que representan un trabajo de escritura muy cuidadoso y consciente.

47. Este crítico alude a la experiencia personal de Sergio Ramírez, que después de luchar contra la dictadura somocista asume una posición de poder, experiencia que lo libera de los planteamientos pesimistas con respecto a la dictadura e incide en el tono irónico de la novela.

48. Ese mismo día también se suicida Macabeo Regidor.

49. Eco alude al poder subversivo del carnaval y a la parodia de las normas que encarna el poder.

50. Según Ivanov (1989: 21), el carnaval debe entenderse como una inversión de las oposiciones binarias.

51. Para Emir Rodríguez Monegal (1979: 409), la parodia representa una desacralización de modelos de la cultura occidental.

52. Al igual que Rodríguez Monegal, Umberto Eco (1989: 11) apunta que la máscara funciona como un medio para ocultar la identidad.

53. En este caso, la máscara de la ficción desaparece y deja a los personajes ante una realidad que avergüenza, pero el abuelo Lisandro, con un conocimiento vasto del pueblo, y aludiendo a la picardía de sus habitantes, afirma que, "desnudos o disfrazados, todos se conocen en este pueblo" (166). 
54. Por este motivo, la novela se convierte en un texto dialógico, donde la realidad es vista desde la perspectiva de varios personajes y no hay una sola voz autoritaria y monológica que se convierta en el centro de toda la narración.

55. Julia Kristeva (1974: 78) considera que esta es una de las principales características de la novela como género literario.

56. Mijail Bajtín (1989: 493) al estudiar la cultura popular en las obras de Nicolás Gogol y François Rabelais afirma que la risa siempre es luminosa, significativa y profunda.

57. Sobre este aspecto, consúltese González, Reynaldo: "Prólogo", en Ramírez, Sergio: Las armas del futuro, Managua, Editorial Nueva Nicaragua, 1987, p. XIX y Morales, Arqueles: "Sergio Ramírez: gobernar con el mismo esmero con que escribo", en Casa de las Américas, vol. 25, núm. 151, 1985, p. 71.

58. Este diálogo entre lo local (nacional) y lo universal se aprecia con mayor claridad en Margarita, está linda la mar, donde el autor entrelaza temas históricos y culturales nicaragüenses con otros de carácter universal como la muerte y la miseria humana.

59. Mijail Bajtín (1989: 473) sostiene que la risa tiene un carácter universal, debido a que, más allá de cualquier particularidad cultural, constituye un rasgo fundamental del ser humano, que lo lleva a reconocerse a sí mismo y le imprime dinamismo a las acciones de la vida.

60. Para Aurelia Dobles (1995: 8), esta obra se nutre de la picaresca española. Considero que la opinión de Dobles debe restringirse al tono picaresco que apunta hacia la subversión y transgresión de códigos, más que al planteamiento de la obra como una novela picaresca.

61. El autor, además de resaltar cómo su vida y su carrera de escritor se han nutrido de la imaginación y del espíritu pragmático de sus abuelos, rescata el valor de la tolerancia como uno de los pilares de su vida que cobra mucha importancia en la década de los noventa.

62. Por su connotación autobiográfica, esta novela guarda una relación con Paradiso (1966) de José Lezama Lima. A pesar de este valor autobiográfico, Un baile de máscaras no tiene la misma dimensión que Paradiso, en el sentido de que apenas presenta el nacimiento del personaje Sergio, mientras que la segunda se adentra en la vida de José Cemí y tiene un carácter formativo y educativo, lo que ha permitido, incluso, que sea calificada como un bildungsroman (Ruiz 1980: 11-2). Es importante agregar que en Paradiso, el personaje José Cemí “sirve para realizar un análisis a fondo, tanto del propio Lezama Lima como de la complicada trama de la realidad nacional, integrada por mitos, magia y poesía, pero también de realidades concretas" (Bellini 1990: 628) y que en esta obra también se le concede un valor esencial a la familia, como lo ha resaltado Raquel Carrió (1996: 548) al afirmar que en Lezama Lima "la familia es síntesis histórica, particularización social, núcleo en el que se cumplen o no las coordenadas y el destino de la nación. En mi opinión, por el trabajo realizado en Un baile de máscaras, Sergio Ramírez comparte esta concepción de Lezama Lima sobre la familia.

63. De acuerdo con Eco, el carnaval es una forma de destruir el poder como centro y funciona como una forma de que la multitud, el pueblo, asuma el poder, aunque sea por un determinado espacio tempo- 
ral.

\section{Bibliografía}

Acuña Ortega, Víctor Hugo (ed.). 1993. Historia general de Centroamérica. Madrid: Sociedad Estatal Quinto Centenario/FLACSO.

Bulmer Thomas, Víctor: 1993. "La crisis de la economía de agroexportación (1930-1945)". En Acuña Ortega, Víctor Hugo (ed.).

Bajtín, Mijail. 1989. Teoría y estética de la novela. Traducción Helena Kriükova y Vicente Cazcarra. Madrid: Taurus.

Ballart, Pere. 1994. Eironeia. La figuración irónica en el discurso literario moderno. Barcelona: Quaderns Crema.

Booth, Wayne. 1986. Retórica de la ironía. Versión castellana de Jesús Fernández Zulaica y Aurelio Matínez Benito. Madrid: Taurus.

Bellini, Giuseppe. 1990. Historia de la literatura hispanoamericana. $2^{\text {a }}$ edición. Madrid: Castalia.

Caballero Wangüemert, María. 1993. "Discurso histórico y carnavalización de la historia: El Juramento de René Marqués”. Revista Iberoamericana (162-163).

Carrió Mendía, Raquel. 1996. “La imagen histórica en Paradiso”. En Lezama Lima, José.

Dobles, Aurelia. 1995. "Picaresca nica”. En La Nación. San José, Costa Rica. 20 de julio.

1995. “Ironía desenmascarada”. En: La Nación. San José, Costa Rica. 23 de julio.

1998. "Nicaragua en el centro de la herida”. En: La Nación. San José, Costa Rica. 1 de marzo.

1999. "Rescate de la memoria herida”. En La Nación, Suplemento Áncora. San José, Costa Rica. 18 de julio.

Eco, Umberto. 1989. "Los marcos de la libertad cómica”. En Eco, Umberto; V. Ivanov y M. Rector: 9-20.

Eco, Umberto; V. Ivanov y M. Rector. ¡Carnaval!. Traducción Mónica Mansour. México: Fondo de Cultura Económica.

Febles, Jorge. 1996. “Dying Players: Ramírez's 'El centerfield' and Dybek's 'Death of the 
Rightfielder”. Confluencia. Revista Hispánica de Cultura y Literatura. 12 (1).

Fernández, V. 1995. “Un baile de máscaras”. En La Nación. San José, Costa Rica; Suplemento Áncora. 20 de agosto.

Gruner, Charles. 1997. The game of humor. New Brunswick (USA)/London: Transaction Publishers.

Ivanov, V. 1989. "La teoría del carnaval como la inversión de los opuestos bipolares”. En Eco, Umberto; V. Ivanov y M. Rector: 21.

Kristeva, Julia. 1974. El texto de la novela. Traducción Jordi Llovet. Barcelona: Editorial Lumen.

Lezama Lima, José. 1996. Paradiso. 2a edición. Madrid: Colección Archivos.

Mora Rodríguez, Arnoldo. 1995. "Las dos últimas novelas de Sergio Ramírez”. En La Nación. San José, Costa Rica. 22 de agosto.

Pulgarín, Amalia. 1995. La metaficción historiográfica. Madrid: Editorial Fundamentos.

Ramírez Mercado, Sergio. 1963. Cuentos. Managua: Editorial Nicaragüense.

1969. Nuevos cuentos. León: Editorial Universitaria.

1970. Tiempo de fulgor. Guatemala: Editorial Universitaria.

1973. De tropeles y tropelías. El Salvador: Editorial Universitaria.

1976. Charles Atlas también muere. México: Joaquín Mortiz.

1977. ¿Te dio miedo la sangre? Caracas: Monte Ávila Editores.

1977. Hombre del Caribe. San José: EDUCA.

1988. Castigo Divino. Madrid: Mondadori.

1989. La marca del zorro. Madrid: Mondadori.

1994. Oficios compartidos. México: Siglo XXI Editores.

1995. Un baile de máscaras. México: Alfaguara.

1998. Margarita, está linda la mar. Madrid: Alfaguara. 
2001. Mentiras verdaderas. México: Alfaguara.

Rodríguez Monegal, Emir. 1979. "Carnaval, antropofagia y parodia". Revista Iberoamericana. 45 (108-109): 401-12.

Ross, Peter. 1991. "The politician as novelist". Antípodas. (3).

Ruiz Barrionuevo, Carmen. 1980. El 'Paradiso’ de Lezama Lima. Madrid: Ínsula.

Sklodowska, Elzbieta. 1991. La parodia en la nueva novela hispanoamericana. Amsterdam/ Philadelphia: John Benjamins Publishing Company.

Starcevic, Dino. 1995. "Largo viaje hacia la noche”. En La República. San José, Costa Rica. 20 de julio.

Taracena Arriola, Arturo. 1993. "Liberalismo y poder político en Centroamérica (1870-1929)”. En Acuña, Víctor Hugo (ed.).

Titler, Jonathan. 1990. Ironía narrativa en la novela hispanoamericana contemporánea. Traducción Carmen Barvo. Colombia: Banco de la República.

Vargas, José Ángel. 1999. Entrevista a Sergio Ramírez, Madrid, España. 9 de noviembre.

Vigara Tauste, Ana María. 1994. El chiste y la comunicación lúdica: lenguaje y praxis. Madrid: Ediciones Libertarias.

Zavala, Lauro. 1993. Humor, ironía y lectura. México: Universidad Autónoma Metropolitana. 